\title{
Evaluation of Different Establishment Methods for Enhancing Productivity and Profitability of Rice under Puddle Condition
}

\author{
M. Mali*, M. Kumar, P.K. Salam, G.K. Sharma and R.R. Saxena \\ SGCARS, Jagdalpur (IGKV, Raipur), India \\ *Corresponding author
}

A B S T R A C T

Keywords

Rice establishment methods and yield attributes and grain yield.

Article Info

Accepted:

20 July 2018

Available Online:

10 August 2018
A field experiment conducted during Kharif season of 2017 under AICRIP, in Alfisols at Instructional cum Research of Shaheed Gundadhoor College and Agricultural Research Station, Jagdalpur, Chhattisgarh, to study grain yield of rice as influenced by different establishment methods under puddle condition. Results indicated that highest grain yield $\left(\mathrm{q} \mathrm{ha}^{-1}\right)$ was registered under the treatment line transplanting method $\left(\mathrm{T}_{1}\right)$ which was at par with treatment wet direct seeded rice using drum seeder $\left(\mathrm{T}_{3}\right)$. The lowest grain yield $\left(\mathrm{q} \mathrm{ha}^{-1}\right)$ was recorded with treatment dry direct sowing method $\left(\mathrm{T}_{5}\right)$.

\section{Introduction}

Rice is a member of the family Poaceae originated from South-East Asia. In world rice has occupied an area of 158.9 million hectares, with a total production of 685.0 million tonnes in 2011 (Anonymous, 2016). In Asian countries, rice is the main major staple crop covering about $90 \%$ of rice grown in the world, thus rice is immensely important to food security of Asia. Rice (Oryza sativa L.) is considered as the 'Global Grain' in 89 nations and it is an important food for more than half of the global population. In India, rice is grown under three major ecosystem: rainfed upland (16\%), irrigated land (45\%) and rainfed lowland $(39 \%)$, with a productivity of $0.87,2.24$, and $1.55 \mathrm{t} \mathrm{ha}^{-1}$, respectively. The slogan 'Rice is life' is most appropriate for India. It contributes 20 to 25 per cent of agriculture GDP.

Method of establishment is one of the cultural practices, which influences the rice crop through its effect on growth and development (Gobi et al., 2006).Transplanting of rice seedlings in the traditional way is a laborious, time consuming and causes drudgery. Nonavailability of labors for transplanting at appropriate time leads to late planting, which results in poor yields. Rice transplanting is 
done manually and requires about 306 man-h $\mathrm{ha}^{-1}$, which is roughly $42 \%$ of the total labor requirement of rice production. Balasubramanian and Hill (2002) stated that direct seeding could be alternative to the traditional transplanting culture but poor germination, uneven crop stands and high weed infestation are among the main constraints to the adoption of direct seeded rice. Direct seed rice refers to the process of establishing a rice crop from seeds sown in the field rather than by transplanting seedlings from nursery (Farooq et al., 2011).

There are three principal methods of DSR: dry seeding (sowing dry seeds into dry soil), wet seeding (sowing pre-germinated seeds into dry soil) and water seeding (seeds sown into standing water). Wet seeding is sowing of pre germinated seed on to puddled soil which is a major crop establishment system of rice culture in Chhattisgarh and also used in other parts of the tropics and subtropics. This method also became mandatory in case of continuous rains, where direct dry seeding, nursery raising is not possible or in delayed condition.

\section{Materials and Methods}

Research trial on "Evaluation of different establishment methods for enhancing productivity and profitability of rice under puddle condition" was conducted at Instructional cum Research Farm, Shaheed Gundadhoor College of Agricultural and Research Station, Jagdalpur, Chhattisgarh during kharif season of 2017. The experiment was laid out in randomized block design with four replications. The different methods of establishment viz., line transplanting $\left(\mathrm{T}_{1}\right)$, random transplanting $\left(\mathrm{T}_{2}\right)$, wet direct seeded rice using drum seeders $\left(\mathrm{T}_{3}\right)$, wet direct seeded rice by broadcasting $\left(\mathrm{T}_{4}\right)$ and direct sowing method (Dry seeded) $\left(\mathrm{T}_{5}\right)$ were adopted.

The variety Durgeswari was taken as a test which parentage are Mahamaya x NSN 5 (MTC-4, IET 11904), maturity duration 130135 days, grain type long slender grain. The crop was established 27.06.17 and harvested on 06.11.17. The soil of the experimental site is characterized as silty loam (fairly leveled). The soil was locally known as Mal (Alfisols). It is well fertile soil belongs to mid land situation of landscape in Jagdalpur. During kharif 2017, a total of $1602.9 \mathrm{~mm}$ rainfall in 82 rainy days was recorded against the normal rainfall of $1195 \mathrm{~mm}$.

\section{Results and Discussion}

Plant height, dry matter accumulation leaf area index, root volume and root dry weight at different durations of rice as influenced by different crop establishment methods

The plant height at different intervals significantly affected due to the different establishment methods (Table 1). At most of stages taller plant observed under treatment line transplanting $\left(\mathrm{T}_{1}\right)$. However, at $90 \mathrm{DAE}$ and harvest which was at par with treatment wet direct seeded rice using drum seeder $\left(\mathrm{T}_{3}\right)$.

Plant height is an important morphological attribute. It is a function of combined effects of genetic make up of a plant, soil nutrient status, seedling vigor and the environmental conditions in which it is grown.

At all the growth periods of observations treatment $\left(\mathrm{T}_{1}\right)$ line transplanting method recorded significantly highest dry matter accumulation. However, during 30 and 90 DAE treatment line transplanting method $\left(T_{1}\right)$ which was at par with treatment wet direct seeded rice using drum seeder $\left(\mathrm{T}_{3}\right)$ with an additional treatment $\left(\mathrm{T}_{2}\right)$ random transplanting method at 30 DAE. In general the leaf area index showed increasing trend from 30 DAE to $90 \mathrm{DAE}$ whereas at harvest stage slightly 
decreases in all establishment methods. At all growth stages treatment line transplanting method $\left(\mathrm{T}_{1}\right)$ recorded significantly higher leaf area index but at 60 and 90 DAE which was at par with treatment wet direct seeded rice using drum seeder $\left(\mathrm{T}_{3}\right)$.

Further, at harvest stage it was found to be non significant. Significantly highest root volume was registered under treatment line transplanting method $\left(\mathrm{T}_{1}\right)$ at all recorded durations and superior to other treatments except at harvest which was at par with treatments random transplanting $\left(\mathrm{T}_{2}\right)$ and wet direct seeded rice using drum seeder $\left(\mathrm{T}_{3}\right)$.

The establishment method under treatment line transplanting $\left(\mathrm{T}_{1}\right)$ registered significantly highest root dry weight at all growth stages except 60 and 90 DAE in which at par with treatment random transplanting $\left(\mathrm{T}_{2}\right)$. Plant height depicts health and vigor of a crop. It is directly proportional with the development of root system and availability of nutrients to the plants (Table 2). Hussain et al., (2013) stated highest plant heights were recorded in transplanted crop in puddled soil $(123.7 \mathrm{~cm})$ whereas the lowest plant height was observed in direct seeded crop.

The dry matter accumulation is the function of number of tillers and leaves, plant height and tillers panicle weight. The release of nutrients while application and its absorption, translocation and conversion of energy for growing parts helped to increase the dry matter accumulation.

These results corroborate with reported by Belder et al., (2005) leaf area index (LAI) is an important parameter of rice canopy because it is directly and positively related to crop photosynthesis. Zhong et al., (2002) revealed that LAI and plant $\mathrm{N}$ status are two major factors that influence tiller production in rice crops.

Number of effective tillers, $50 \%$ flowering, no of panicle, panicle length, grains panicle ${ }^{-}$ 1 and Panicle weight at different durations of rice as influenced by different crop establishment methods

Significantly highest days taken to $50 \%$ flowering was recorded under treatment wet direct seeded rice using drum seeder $\left(T_{3}\right)$ which was at par with treatment wet direct seeded rice by broadcasting $\left(\mathrm{T}_{4}\right)$. The treatment dry direct sowing method $\left(\mathrm{T}_{5}\right)$ flowers $50 \%$ earlier than rest of the treatments (Table 4). Significantly highest number of effective tillers hill $^{-1}$ was obtained with treatment line transplanting $\left(\mathrm{T}_{1}\right)$ and superior over rest of the treatments. Tillering plays an important role in determining rice grain yield since it is closely related to panicle number per unit ground area. Significantly longest panicle was registered with treatment line transplanting method $\left(\mathrm{T}_{1}\right)$ which was at par with treatment wet direct seeded rice using drum seeder $\left(T_{3}\right)$. The shortest panicle was observed under treatment dry direct sowing method $\left(\mathrm{T}_{5}\right)$. Goel and Verma (2000) found higher panicle length from the transplanting method than the direct sowing method. Significantly highest number of panicle hill ${ }^{-1}$ was registered with treatment line transplanting method $\left(\mathrm{T}_{1}\right)$ which was at par with treatment wet direct seeded rice using drum seeder $\left(T_{3}\right)$. The lowest number of panicle hill $^{-1}$ was observed under treatment dry direct sowing method $\left(\mathrm{T}_{5}\right)$. Significantly highest number of grains panicle ${ }^{-1}$ was registered under the treatment random transplanting method which was at par with treatment wet direct seeded rice using drum seeder $\left(\mathrm{T}_{3}\right)$, line transplanting method $\left(\mathrm{T}_{1}\right)$ and wet direct seeded rice by broadcasting $\left(\mathrm{T}_{4}\right)$. The significantly highest Panicle weight (g) was registered under the treatment line transplanting method $\left(\mathrm{T}_{1}\right)$ which was at par with treatment random transplanting $\left(\mathrm{T}_{2}\right)$ and wet direct seeded rice using drum seeder $\left(\mathrm{T}_{3}\right)$ (Table 4). The lowest panicle weight was 
recorded with treatment dry direct sowing method $\left(\mathrm{T}_{5}\right)$. Rajkhowa and Gogoi (2004) found more productive tillers in transplanting of seedlings than sprouted seeds.

Chlorophyll $\mathrm{mg} \mathrm{gm}^{-1}$, nutrient content and nutrient uptake $\mathrm{kg} \mathrm{ha}^{-1}$ in grain and straw of rice as influenced by different crop establishment methods

The data revealed that crop establishment methods were found to be non significant effect on chlorophyll ' $a$ ', 'b' and total contents (Table 3). This might be due to all establishment methods treatments got equal nutrients. Significantly highest $N$ content in grain and straw was registered under the treatment line transplanting method $\left(\mathrm{T}_{1}\right)$ which was at par with treatments random transplanting $\left(\mathrm{T}_{2}\right)$ and with an additional treatment wet direct seeded rice using drum seeder $\left(\mathrm{T}_{3}\right)$ in straw. While, highest $\mathrm{P}$ content in grain and straw was registered under the treatment line transplanting method which was at par with treatments wet direct seeded rice using drum seeder $\left(\mathrm{T}_{3}\right)$ and with an additional treatment random transplanting $\left(\mathrm{T}_{2}\right)$ in grain. Significantly highest K content in straw was registered under the treatment line transplanting method $\left(\mathrm{T}_{1}\right)$ which was at par with treatment wet direct seeded rice using drum seeder $\left(\mathrm{T}_{3}\right)$. Further, grain $\mathrm{K}$ content was found to be non significant. Significantly highest $\mathrm{N}, \mathrm{P}$ and $\mathrm{K}$ uptake in grain and straw were recorded under treatment line transplanting method $\left(\mathrm{T}_{1}\right)$ which was at par with treatment wet direct seeded rice using drum seeder $\left(\mathrm{T}_{3}\right)$. The lowest $\mathrm{N}$ uptake in grain was observed with treatment dry direct sowing method $\left(\mathrm{T}_{5}\right)$. The nitrogen, phosphorus and potassium efficiencies are accelerated due to different methods of establisment of rice. This is in agreement with other studies where the higher nutrient uptake with treatment line transplanting method $\left(\mathrm{T}_{1}\right)$ followed by treatment wet direct seeded rice using drum seeder $\left(\mathrm{T}_{3}\right)$ might be attributed to solubilization of native nutrients, their mobilization, proper space,light and accumulation of different nutrients in different plant parts. These results are also in agreement with the findings obtained by Sharma et al., (2007).

Test weight, yield, harvest index and economics of rice as influenced by different crop establishment methods

The test weight data revealed that establishment methods found to be non significant (Table 5). Gill et al., (2008) found test weight did not differ significantly on account of method of crop establishment.

The significantly highest grain yield ( $\mathrm{q} \mathrm{ha}{ }^{-1}$ ) was registered under the treatment line transplanting method $\left(\mathrm{T}_{1}\right)$ which was at par with treatment wet direct seeded rice using drum seeder $\left(T_{3}\right)$. The lowest grain yield ( $q$ $\mathrm{ha}^{-1}$ ) was recorded with treatment dry direct sowing method $\left(\mathrm{T}_{5}\right)$. The significantly highest straw yield $\left(\mathrm{q} \mathrm{ha}^{-1}\right)$ was registered under the treatment line transplanting method $\left(\mathrm{T}_{1}\right)$ which was at par with treatment random transplanting $\left(\mathrm{T}_{2}\right)$ and wet direct seeded rice using drum seeder $\left(\mathrm{T}_{3}\right)$. The lowest straw yield notice under treatment dry direct sowing method $\left(\mathrm{T}_{5}\right)$. The data revealed that harvest index of rice found to be non significant (Table 5). Many factors determine the yield for rice crop during cultivation such as soil, cultivar, season, environment, planting time, methods of establishment, water management, weed control, cropping pattern, source, form, rate, time of application and method of application. Mankotia et al., (2009) found similar results that among four methods of rice establishment transplanted method of paddy resulted in significantly higher grain yield (3.98 $\left.\mathrm{t} \mathrm{ha}^{-1}\right)$ followed by drum seeding(3.37 t $\left.\mathrm{ha}^{-1}\right)$, broadcast $\operatorname{seeding}\left(3.27 \mathrm{t} \mathrm{ha}^{-1}\right)$ of sprouted seeds and row seeding $\left(2.95 \mathrm{t} \mathrm{ha}^{-1}\right)$ in 
prepared bed. Significantly highest gross return was registered with treatment line transplanting method $\left(\mathrm{T}_{1}\right)$ over rest of the treatments.

Transplanted flooded rice leads to high losses of water through puddling, surface evaporation and percolation. Significantly highest net return and $\mathrm{B}$ : $\mathrm{C}$ ratio was registered with treatment wet direct seeded rice using drum seeder $\left(\mathrm{T}_{3}\right)$ over rest of the treatments. Further, treatment dry direct sowing method $\left(\mathrm{T}_{5}\right)$ registered lowest gross, net and B: $C$ ratio (Table 6). Similar finding was reported by Rana et al., (2014) higher B: $\mathrm{C}$ cost ratio under direct seeding of sprouted seed than transplanting methods due to saving of irrigation water and labour,

In conclusion, the significantly highest grain yield $\left(\mathrm{q} \mathrm{ha}^{-1}\right)$ was registered under the treatment line transplanting method $\left(T_{1}\right)$ which was at par with treatment wet direct seeded rice using drum seeder $\left(\mathrm{T}_{3}\right)$. The lowest grain yield $\left(\mathrm{q} \mathrm{ha}{ }^{-1}\right.$ ) was recorded with treatment dry direct sowing method $\left(\mathrm{T}_{5}\right)$.The significantly highest straw yield $\left(\mathrm{q} \mathrm{ha}^{-1}\right)$ was registered under the treatment line transplanting method $\left(\mathrm{T}_{1}\right)$ which was at par with treatment random transplanting $\left(\mathrm{T}_{2}\right)$ and wet direct seeded rice using drum seeder $\left(\mathrm{T}_{3}\right)$. The lowest straw yield notice under treatment dry direct sowing method $\left(\mathrm{T}_{5}\right)$. highest gross return was registered with treatment line transplanting method $\left(\mathrm{T}_{1}\right)$ over rest of the treatments. Transplanted flooded rice leads to high losses of water through puddling, surface evaporation and percolation. Significantly highest net return and B: C ratio was registered with treatment wet direct seeded rice using drum seeder $\left(\mathrm{T}_{3}\right)$ over rest of the treatments. Further, treatment dry direct sowing method $\left(\mathrm{T}_{5}\right)$ registered lowest gross, net and $\mathrm{B}$ : $\mathrm{C}$ ratio.

\section{References}

Anonymous.2016. Krishi Darshika, Annual publication of Directorate of Extension Services, IGKV, Raipur (C.G.)

Balasubramanian, V. and Hill, J. E. 2002. Direct seeding of rice in Asia: Emerging issues and strategic research needs for the 21 st century. In "Direct Seeding: Research Strategies and Opportunities" (S. Pandey, M. Mortimer, L. Wade, T. P. Tuong, K. Lopez, and B. Hardy, Eds.), pp. 15-39. International Rice Research Institute, Los Banos, Philippines.

Belder, P., Bouman, B.A.M., Spiertz, J.H.J., Peng, S., Castaneda, A.R. and Visperas, R.M. 2005. Crop performance, nitrogen and water use in flooded and aerobic rice. Plant and Soils, 273: 167-82.

Gobi, R.,Pandian, B.J.and Karaka, S. 2006. Evaluation of stand establishment methods and split application of $\mathrm{N}$ and $\mathrm{K}$ for hybrid rice (CoRH-2).Crop Research. 32(3): 275-278.

Gill,M.S., Ashwini,K. and Pardeep, K. 2008. Growth and yield of rice (Oryza sativa) cultivars under various methods and times of sowing. Indian Journal of Agronomy, 51(2): 123-127.

Goel, A.C. and Verma, K.S. 2000. Comparative study of direct seeding and transplanting of rice. Indian J. Agril. Res. 34(3): 194-196.

Farooq., M, Siddique., K.H.M., Rehman.,H, A.T., Dong, J. L. and Wahid, A. 2011. Rice direct seeding: Experiences, challenges and opportunities. Soil Tillage Res, 111: 87-98.

Hussain, S., Ramzan, M., Rana, M. A., Mann, R. A. and Akhter, M. 2013. Effect of various planting techniques on yield and yield components of rice. The Journal of Animal \& Plant 
Sciences, 23(2): Page: 672-674.

Mankotia, B.S., Sekhar, J and Negi, S.C. 2009. Effect of crop establishment techniques on productivity of ricewheat cropping system. Oryza. 46 (3): 205-208.

Rajkhowa, D.J. and Gogoi, A.K. 2004. Effect of planting methods and weed management on transplanted summer rice. Indian J. Weed Sci. 36(1/2): 119121.Sciences, 23(2): 2013, Page: 672674.

Rana, M. M., Mamum, M. A., Zahan, A., Ahmed, M. N. and Mridha, M. A. J. 2014. Effect of planting methods on yield and yield attributes of short duration Aman rice. American Journal of Plant Sciences. 5: 251-255.

Sharma, R. P., Patha, S.K. and Singh, R.C. 2007. Effect of nitrogen and weed management practices in direct seeded rice (Oryza sativa) under upland conditions. Indian Journal of Agronomy. 52:114-119.

Zhong, X., Peng, S., Sheehy, J.E., Visperas, R.M. and Liu, H. 2002. Relationship between tillering and leaf area index: quantifying critical leaf area index for tillering in rice. J. Agric. Sci., 138: 269-279.

\section{How to cite this article:}

Mali, M., M. Kumar, P.K. Salam, G.K. Sharma and Saxena, R.R. 2018. Evaluation of Different Establishment Methods for Enhancing Productivity and Profitability of Rice under Puddle Condition. Int.J.Curr.Microbiol.App.Sci. 7(08): 3340-3345.

doi: https://doi.org/10.20546/ijcmas.2018.708.357 